\title{
Питання психології
}

УДК 159.9:34.01

DOI: $10.33099 / 2617-6858-20-56-3-140-146$

Чепур О. О. головний судовий експерт,

Полтавського науково-дослідного,

експертно-криміналістичного иентру МВС Украӥни

https://orcid.org/0000-0001-7830-1098

\section{СПЕЦИФІКА МЕХАНІЗМІВ ЗДІЙСНЕННЯ ПСИХОЛОГІЧНОГО ВПЛИВУ СЛІДЧИМИ НА ПІДОЗРЮВАНИХ У ПРОЦЕСІ ПРОФЕСІЙНОӤ ДІЯЛЬНОСТІ}

Стаття присвячена висвітленню механізмів та чинників психологічного впливу слідчих у прочесі професійної діяльності. Подано теоретичний аналіз проблеми психологічного впливу у діяльності слідчого, щзо узагальнено в теоретичній моделі правомірного психологічного виливу. Проаналізовано механізми і закономірності здійснення психологічного впливу слідчого на підозрюваного у прочесі слідчих дій.

Ключові слова: психологічний вплив; слідчі; механізми; професійна діяльність; слідчі дії.

Постановка проблеми. Професійна діяльність слідчого $\epsilon$ складною як за змістом, адже передбачає розкриття заплутаного ланцюгу поведінкових актів і мотивів підозрюваного; так і за формою діяльності, оскільки передбачає постійну інтенсивну взаємодію 3 іншими людьми в умовах емоційної напруги, моральноетичної відповідальності. 3 огляду на головну мету діяльності слідчого розкриття злочину - закономірними виступають специфічні труднощі, 3 якими працівнику доводиться зустрічатися, адже майже в усіх випадках особа, що підозрюється у скоєнні злочину, намагається протидіяти слідству, приховувати факти, висувати хибні мотиви своїх вчинків та послідовності дій, що часто вимагає застосування психологічного впливу.

Аналіз останніх досліджень i публікацій. Проблема психологічного впливу з боку працівників правоохоронних органів на учасників кримінального процесу тривалий час вивчається науковцями. Зокрема, загальні закономірності впливу працівників правоохоронних органів висвітлені в дослідженнях В.О. Коновалової, М.В. Костицького, Ф.М.Сокирана, Ю.В.Чуфаровського, Н.Є.Мілорадової, та інших. Особливості класифікації методів психологічного впливу висвітлені в дослідженнях таких вчених як В.П. Бахін, В.В Бедь, Ю.В.Шепитько.

Ф.М. Сокиран під психологічним впливом на досудовому слідстві розуміє комплекс прийомів, які застосовуються в процесі передачі, опрацювання та використання доказової інформації, викликаючи відповідну реакцію, що дозволяє діагностувати психічний стан особи, контролювати хід іï думок, ставлення до певних фактів для зміни іiі поведінки в напрямі одержання правдивої i повної інформації [4]. Спираючись на погляди M.M. Руденка [3], у якості критеріїв правомірності психологічного впливу у слідчих діях виступають правомірне використання впливу (недопущення насильства), можливість особистістю обирати комунікативні стратегії; відсутність психологічного чи фізичного насильства; здійснення впливу у умовах доброчесності та поваги до гідності особистості, тощо. Як зауважує І.В. Шинкаренко [5] стосовно даної проблеми, щоб ефективно застосовувати вплив у слідчих діях працівник повинен професійно володіти уміннями встановлювати контакт, недирективно керувати діалогом; бути чутливим до невербальних виявів допитуваного, тощо. При цьому, професійна діяльність слідчих здійснюється в умовах «агресивного комунікативного середовища» (за висловом I.В. Шинкаренко), під яким маються на увазі галузі контактів слідчого, пов'язані 3 негативним емоційним напруженням, протистоянням позиції, відкритим конфліктом різного ступеня, виявами психологічної боротьби. Саме перебування в такому агресивному середовищі вимагає від слідчого умілого застосування психологічного впливу. Узагальнивши наукові позиції вчених можемо зазначити, що психологічний вплив у діяльності слідчого має бути виключно правомірним 3 огляду на недопустимість протиправних дій та порушень 3 боку самих працівників правоохоронних органів. 


\section{Питання психології}

Тож, сутність психологічного впливу у слідчих діях достатньо багатогранна i вимагає емпіричного осягнення, що зазначалося автором раніше (Бабенко О.О. [1]). На основі узагальнення результатів теоретичного аналізу означеної проблеми розроблено модель правомірного психологічного впливу у слідчих діях. Дана модель описує два аспекти даного впливу: аспект суб'єктних характеристик слідчого та ситуаційні та об'єктні аспекти психологічного впливу у слідстві. Зокрема, у даній моделі визначено послідовно функціонуючі рівні правової свідомості (Землянська О.В. [2]), особистісних характеристик слідчого, його поведінкових особливостей, методів і видів впливу, технік впливу. Також, дана модель відображає вплив ситуаційних характеристик на процес впливу та особливостей об'єкту впливу.

Разом із ти, проблема визначення сутності психологічного впливу слідчого у процесі професійної діяльності залишається остаточно не вивченою та потребує конкретизації механізмів даного впливу у слідчих діях.

Мета статті. Тож, метою даної статті $€$ опис механізмів i закономірностей здійснення психологічного впливу слідчими на підозрюваних у процесі професійної діяльності

Методи дослідження. Основними методами дослідження стали загальні психодіагностичні методи (анкетування, опитування, спостереження) та статистичні методи (факторний аналіз).

Дослідження особливостей психологічного впливу у професійній діяльності слідчого на прикладі слідчих дій здійснювалось впродовж 2017-2019 років. Експериментальну групу склали 106 досліджуваних слідчих органів національної поліції України Полтавської та Харківської областей. У вибірці 62 досліджуваних працюють на посаді слідчих та 44 займають більш високі посади (старший слідчий, керівники підрозділів); 72 респонденти $\epsilon$ молодими спеціалістами (мають стаж роботи на даній посаді до 3 років включно) і 34 досліджувані умовно визначені нами як досвідчені фахівці.

Нами проаналізовані особливості особистісних детермінант психологічного впливу слідчих у професійній діяльності - їх стратегії поведінки у конфлікті, мотивація досягнення успіху, акцентуації характеру та типи міжособистісної взаємодії. Виявлено, що переважаючими стратегіями поведінки слідчих у конфлікті $\epsilon$ компроміс та уникнення. Встановлено, що стратегії поведінки у конфлікті слідчих не залежать від стажу роботи, проте суттєво змінюються зі зміною посади. Так, слідчі більше направлені на прояви суперництва як аспекту впливу на підозрюваного, натомість старші слідчі та керівники слідчих органів більше направлені на прояви компромісу та уникнення конфліктних ситуацій, налаштовані на їх ефективне вирішення.

Ми визначили, що слідчі характеризуються переважанням середнього показника мотивації досягнення успіху, що не залежить від стажу роботи, проте більше виражений серед старших слідчих та представників керівництва.

Слідчі мають дещо виражену схильність до прояву тенденцій демонстративності та гіпретимності, що полегшує застосування засобів психологічного впливу у професійній діяльності 3 огляду на підвищений енергетичний тонус у взаємодії, можливість заражати емоціями оточуючих людей та спроможність здійснювати вплив на оточуючих на рівні характерологічних якостей. Слідчим не властиві тривожна, екзальтована, дистимна та циклотимна акцентуації, що засвідчує тенденцію у досліджуваних бути частіше суб'єктом психологічного впливу, ніж його об'єктом 3 огляду на прояви сили характеру, активність та самостійність. Хоча, загалом, прояви виражених акцентуацій характеру не $\epsilon$ загальною тенденцією для досліджуваної групи.

Слідчим характерні виражені в межах нормативних значень прояви владнолідируючого та незалежно-домінуючого типу взаємодії, що поєднуються із їх спроможністю до співпраці, конвенційності та відповідально-великодушного спілкування. При цьому, виявлено, що акцентуації характеру та типи міжособистісної взаємодії не відрізняються у слідчих 3 різним стажем роботи та займаною посадою, будучи глибинними психологічними характеристиками.

Разом із тим, описані емпіричні дані не дають цілісного розуміння специфіки психологічного впливу слідчих на 


\section{Питання психології}

підозрюваних з огляду на відсутність опису внутрішніх закономірностей в межах детермінант психологічного впливу, його реалізації. Здійснений опис результатів дослідження має скоріше феноменологічний характер, описує діагностовані дані. Проте, для розуміння сутності здійснення психологічного впливу, виокремлення його механізмів та закономірностей як складно організованого та системного явища, нами здійснений факторний аналіз сукупності емпіричних даних.

Метою факторного аналізу виступало: 1) узагальнення емпіричних даних; 2) їх укрупнення для можливості визначення найбільш загальний його ознак та тенденцій; 3) виявлення прихованих зв'язків i закономірностей в структурі детермінант психологічного впливу слідчого на підозрюваного у процесі слідчих дій. Для цього нами застосований факторний аналіз iз процедурою Varimax-обертання 3 нормалізацією Кайзера.

Для проведення факторного аналізу виокремлено 24 змінні, до яких увійшли: показник вираженості мотивації досягнення; 10 показників вираженості акцентуацій характеру за методикою ЛеонгардаШмішека; 5 показників, що характеризують стратегії поведінки у конфлікті (виявлені за методикою К. Томаса); 8 показників, що характеризують типи міжособистісної взаємодії досліджуваних, виявлені за методикою Л.М.Собчик. За результатами проведення факторного аналізу (міра виборчої адекватності Кайзера-МайєераОлкіна $=0,540)$ виявлено 8 факторів, які описують 74,6\% загальної дисперсії ознак.

До першого фактору «Стратегія домінування у поведінці слідчого-прагнення до співпраці 3 підозрюваним» (24,683\% сумарної дисперсії, факторна вага становить $5,924)$ увійшли такі компоненти як «Прямолінійно-агресивний тип взаємодії» $(0,873)$, «Владно-лідируючий тип взаємодії» $(0,871)$, «Незалежно-домінуючий тип взаємодії» $(0,868), \quad$ «Недовірливоскептичний тип взаємодії» $(0,719)$, «Суперництво як стратегія поведінки у конфлікті» $(0,648)$. Семантика даного фактору охоплює переважання домінуючих стратегій у взаємодії слідчого як базових для здійснення психологічного впливу на підозрюваного. Спираючись на переважання незалежно-домінуючого та прямолінійно- агресивного типів взаємодії, направленість слідчих на доведення своєї правоти як базової тенденції взаємодії, проявів суперництва, активного протистояння підозрюваному, слідчий спроможний успішно здійснювати психологічний вплив відносно підозрюваного, адже саме властиві таким типам взаємодії особистісні характеристики - домінантність, незалежність, настійливість, самодостатність, деяка агресивність виступають саме тими якостями, що складають основу особистісного потенціалу для здійснення впливу. Тобто, властива слідчим домінантність у системі міжособистісних стосунків виступає осново впливу та суперництва. Зміст даного фактору доводиться наявністю негативних кореляцій зі змінними: «Відповідальновеликодушний тип взаємодії» $(-0,804)$, «Співпрацюючий-конвенційний тип взаємодії» $(-0,770), \quad$ «Екзальтована акцентуація характеру» $(-0,573)$. Тобто, негативна кореляція згаданих вище змінних доводить, що агресивна та домінуюча стратегія взаємодії $є$ одночасно і $є$ умовою ефективного психологічного впливу, i унеможливлює (знаходиться на протилежному полюсі у даному факторі) здійснення відвертого спілкування між слідчим та підозрюваним.

Другий фактор «Демонстративність та наполегливість як характерологічна детермінанта впливу слідчого» (12,367\% сумарної дисперсії, факторна вага становить $2,968)$ включає такі змінні як «Застрягаюча акцентуація характеру» $(0,793)$, «Демонстративна акцентуація характеру» $(0,782)$, «иклотимна акцентуація характеру» $(0,597)$. Поєднання таких змінних у факторі розкриває цікаве комбінування характерологічних особливостей слідчих як детермінанти їх психологічного впливу у процесі слідчих дій. Зокрема, характерологічною основою впливу у слідчих діях виступає властива багатьом представникам вибірки демонстративність, прагнення перебувати центрі уваги в соціальних стосунках, що за допомогою розвинутих механізмів соціального зараження, навіювання та об'єднання навколо себе демонстративної особи дозволяє легко навіювати, впливати на оточуючих. Властиві слідчому акцентуйовані риси характеру виступають 


\section{Питання психології}

засобом впливу на підозрюваного, його демонстративність привертає увагу підозрюваного та налаштовує його несвідомо слідувати словам слідчого. Його застрягання як схильність надмірно центруватися на певній діяльності: 1) створює атмосферу загальної включеності у процес слідства; 2) є основою для надмірної наполегливості у досягненні необхідного результату слідства. Циклотимні риси створюють для слідчого неповторну емоційну атмосферу в процесі професійної діяльності, яка «затягує» підозрюваного та дозволяє реалізувати вплив. Тож, характерологічні особливості слідчого $\epsilon$ вагомою детермінантою психологічного впливу у процесі слідчих дій.

До третього фактору «Серйозність, виваженість i наполегливість слідчого як детермінанта ефективного психологічного впливу» $(8,674 \%$ сумарної дисперсії, факторна вага становить 2,082) увійшли такі змінні як «Дистимна акцентуація характеру» $(0,819)$ та «Гіпертимна акцентуація характеру» $(-0,621)$. Зміст даного фактору відображає важливість дистимних рис характеру у професійній діяльності слідчого та здійсненні ним психологічного впливу. Зокрема, мова йде про наполегливість, виваженість, послідовність, деяку поміркованість, тощо. Такі його якості $\epsilon$ основою для цілеспрямованого та продуманого застосування засобів впливу у процесі слідчих дій. Зміст цього фактору доводить наявність у його складі змінної «Гіпертимна акцентуація характеру» із негативною кореляцією. Тобто, у даному випадку акцентується увага на планомірності та поступовості дій слідчого у контексті впливу, а не на його гіпертимних рисах - активності, відкритості, підвищеному емоційному тонусі. Якщо зміст другого фактору наголошує на важливості активних та наполегливих дій при застосуванні впливу, то зміст третього фактору більше відображає необхідність чіткого планування та виваженості в реалізації впливу відносно підозрюваного.

Четвертий фактор «Потреба у спілкуванні слідчого та його схильність брати на себе обов'язки» $(7,547 \%$ сумарної дисперсії, факторна вага становить 1,811) складають такі змінні як «Покірносором'язливий тип міжособистісної взаємодії» $(0,790)$ та «Залежно-послушний тип взаємодії» $(0,700)$. Зміст даного фактору описує тенденцію, повністю протилежну тенденції із першого фактору. У даному випадку мова йде про схильність слідчих до залежності від системи соціальних контактів, схильність до постійного комуні кування 3 людьми, але не на засадах керівництва та управління соціальним оточенням (як у першому факторі), а на засадах підкорення існуючим стандартам та думці оточуючих, «спроможності слідувати зі іншими людьми». Такі характеристики, що складають зміст даного фактору, об'єднані і знаходяться в негативних кореляційних зв'язках із більшістю показників домінування, керування та самодостатності слідчого. Відповідно, змінні, які складають даний фактор, більше описують перепони в реалізації психологічного впливу у слідчих діях, ніж засоби його реалізації, адже якості підлеглості, залежності не імпонують системі впливу на іншу особистість, а ставлять самого слідчого у ситуацію залежності від інших людей. Імовірно, в контексті здійснення впливу, мова акцентується на прагненні слідчих до взаємодії, схильності брати на себе зобов'язання, що хоч i граничить iз залежністю від соціуму, проте і має інший аспект - професійної відповідальності в діяльності слідчого.

До п'ятого фактору «Врівноваженість та уважність до дрібниць як чинник успішної діяльності слідчого» $(6,541 \%$ сумарної дисперсії, факторна вага становить $1,57)$ увійшли такі змінні як «Мотивація досягнення» $(0,808), \quad$ «Педантична акцентуація характеру» $(0,648)$, «Збудлива акцентуація характеру» $(0,581)$. Зміст даного фактору описує унікальне поєднання емпіричних даних, що стосуються вираженості педантичної та збудливої акцентуацій характеру слідчого, та вираженості у нього мотивації досягнення у спіху у професійній діяльності. Відповідно, семантику даного фактору ми інтерпретуємо як поєднання рис врівноваженості нервової системи, спроможності витримувати тривалий час навантаження, контролювати свої емоційні прояви із рисами педантичності - уважністю до дрібниць, прискіпливістю, наполегливістю. Саме поєднання таких рис найбільш повною мірою поєднується, за результатами 


\section{Питання психології}

факторного аналізу, із мотивацією на досягнення успіху у діяльності слідчого. Мова в даному випадку, скоріше за все, йде про те, що діяльність слідчого при всій іiі багатогранності, сприймається як така, що вимагає тривалої роботи 3 документацією, застосування аналітичних умінь та виваженості. Саме це і розцінюється слідчими як фактор досягнення успіху у професійній діяльності. А сам момент застосування психологічного впливу, гідно даного фактору, передбачає постійне відслідковування слідчим зручного моменту та його ефективного застосування. Більше того, даний фактор розкриває важливу якість слідчого для здійснення впливу спостережливість, яка як раз і $є$ поєднанням умінь контролювати свою поведінку, скеровуючи увагу на об'єкт спостереження, та рис педантизму і уважності до дрібниць.

Шостий фактор «Спроможність слідчого до реалізації однієї лінії поведінки як чинник успішного психологічного впливу» $\quad(5,391 \%$ сумарної дисперсії, факторна вага становить 1,294) складають змінні «Співробітництво як стратегія поведінки у конфлікті» $(0,847)$ та «Компроміс як стратегія поведінки у конфлікті» (-0,741). Зміст цього фактору яскраво відображає важливість у сукупності професійно вагомих якостей слідчого спроможності тривалий час реалізувати обрану комунікативну стратегію у слідчих діях, що призведе засобами психологічного впливу до співробітництва підозрюваного зі слідчим. Мова йде про використання стратегії співробітництва, коли слідчий, пропонуючи підозрюваному віднаходження правдивого вирішення питання, постійно утримуе увагу на необхідності співпрацювати зі слідчими органами та не приховувати свідчення. Цікавим $\epsilon$ те, що в даному випадку мова не йде про досягнення компромісу, коли кожна зі сторін протистояння відмовляються від певних своїх інтересів. Тобто, можемо стверджувати, що, згідно даного фактору, успішний вплив у слідчих діях не має ознак «торгів» та досягнення взаємовигідних домовленостей. Необхідність дачі правдивих свідчень постулюється слідчим як данність, яку підозрюваний має прийняти і не суперечити їй. Лише за цієї умови, а не за умови компромісу з слідчими органами, підозрюваний буде давати правдиві свідчення та ефективно буде застосовано психологічний вплив на підозрюваного у процесі слідчих дій.

До сьомого фактору «Емоційність i поміркованість як засоби перешкоджання ефективному психологічному впливу у слідчих діях» (5,066\% сумарної дисперсії, факторна вага становить 1,216) увійшли змінні «Емотивна акцентуація характеру» $(0,896)$ та «Тривожна акцентуація характеру» $(0,675)$. Зміст цього фактору описує поєднання емотивних (чуйності, емоційності, чутливості) та схильності до тривожності як чинників, що перешкоджають ефективній реалізації психологічного впливу слідчими у процесі професійної діяльності. Через надмірну центрованість на власному емоційному стані та тривожність, наявність негативних передчуттів стосовно перебігу подій у майбутньому, слідчий може допускати помилки. Сам емоційний фон, що описується даними акцентуаціями, не $\epsilon$ сприятливим для психологічного впливу на підозрюваного і тому даний фактор займає останні рангові позиції за факторною вагою. Отже, риси тривожності, емоційності та надмірної поміркованості у прийнятті рішень, за результатами факторизації, виступають перешкодами, які ускладнюють прояви психологічного впливу у слідчих діях.

Восьмий фактор «Уникнення конфліктної ситуації за умови відсутності поступок як техніка психологічного впливу слідчого» $(4,336 \%$ сумарної дисперсії, факторна вага становить 1,041) включає змінні «Пристосування як стратегія поведінки у конфлікті» $(-0,655)$ та «Уникнення як стратегія поведінки у конфлікті» $(0,866)$. Зміст цього фактору відображає вагомість стратегії уникнення протистояння як засіб психологічного впливу слідчого на підозрюваного при недопустимості пристосування у конфлікті та прийняття сторони опонента. Мова у даному випадку йде про вагомість уникати відкритого протистояння слідчим, використовувати «слідчі пастки», «приховані засоби психологічного впливу», але таким чином, щоб не проявляти активну протидію до підозрюваного, і не «здавати власні позиції» відносно вирішення протиріччя. Слідчому для отримання результату слідчих дій не допустимо 


\section{Питання психології}

підлаштовуватися під манеру поведінки підозрюваного, пристосовуватись до тих вимог, які представляє підозрюваний. Проте, таку взаємодію слідчий, згідно процесуального кодексу, реалізує у безконфліктній манері.

Висновки та перспективи подалыших розвідок у даному напрямку. Ефективний психологічний вплив досягається за рахунок таких механізмів: проявів стратегії домінування у поведінці слідчого; проявів демонстративності слідчого та наполегливості працівника; прояв рис виваженості та наполегливості у професійній діяльності та взаємодії 3 підозрюваним; здійснення професійної діяльності на засадах емоційної врівноваженості та уважності до дрібниць, що дає можливість відшукати сприятливу для впливу ситуацію взаємодії 3 підозрюваним; спроможність до реалізації однієї лінії поведінки без «укладання компромісів» із підозрюваним, уникнення відкритих конфліктів та реалізація вплив у прихованому для підозрюваного вигляді. Такі механізми $\epsilon$ найбільш дієвими $\mathrm{y}$ професійній діяльності слідчого, адже дозволяють здійснювати вплив на засадах емоційного контролю, домінуючої позиції та наполягання на обраній тактиці взаємодії. Ефективному психологічному впливу у слідчому процесі заважають прояви емоційності, чутливості, зміна стратегії поведінки слідчого, досягнення «компромісів» із підозрюваним та підлаштування до нього у процесі слідчих дій.

Разом із цим, проблема використання правомірного психологічного впливу слідчими у професійній діяльності залишається остаточно не вивченою, зокрема, перспективою подальших розвідок у даному напрямку може слугувати розробка спеціальної програми розвитку навичок впливу для слідчих та перевірка ii ефективності.

\section{Список використаних джерел}

1. Бабенко О. О. Теоретичний аналіз можливості використання психологічного впливу у роботі слідчого під час проведення допиту. Науковий вісник Херсонського державного університету. Серія: Психологічні науки. 2017. Вип. 6. С. 160-164.

2. Землянська О. В. Судово-психологічна експертиза : навч. посіб. Харків : Нац. ун-т внутр. справ, 2013. $300 \mathrm{c}$.

3. Руденко М.М. Класифікація методів психологічного впливу в оперативно-розшуковій діяльності. Вісник Запорізького юридичного інституту Дніпропетровського держсавного університету внутрішніх справ. 2009. № 1. С. 137-144.

4. Сокиран Ф.М., Сокиран М.Ф. Характеристика тактичних прийомів психологічного впливу у криміналістичній діяльності слідчого. Криміналістичний вісник. 2014. №1 (21). С.45-52.

5. Шинкаренко I.O. Особливості комунікативної компетентності слідчих. Психологічні засади забезпечення службової діяльності працівників правоохоронних органів: матеріали II Всеукраїнської науково-практичної конферениії (в авторській редакції), (м. Кривий Ріг, 07 лютого 2019 року). Кривий Ріг, 2019. С.291-294.

\section{References}

1. Babenko O. O. Teoretychnyi analiz mozhlyvosti vykorystannia psykholohichnoho vplyvu u roboti slidchoho pid chas provedennia dopytu [Theoretical analysis of the possibility of using psychological influence in the work of the investigator during the interrogation]. Naukovyi visnyk Khersonskoho derzhavnoho universytetu. Seriia: Psykholohichni nauky. 2017. Vyp. 6. S. 160-164. (in Ukrainian)

2. Zemlianska O. V. Sudovo-psykholohichna ekspertyza [Forensic psychological examination]: navch. posib. Kharkiv : Nats. un-t vnutr. sprav, 2013. 300 s. (in Ukrainian).

3. Rudenko M.M. Klasyfikatsiia metodiv psykholohichnoho vplyvu v operatyvno-rozshukovii diialnosti.[ Classification of methods of psychological influence in operative-search activity] Visnyk Zaporizkoho yurydychnoho instytutu Dnipropetrovskoho derzhavnoho universytetu vnutrishnikh sprav. 2009. № 1. S. $137-$ 144. (in Ukrainian).

4. Sokyran F.M., Sokyran M.F. Kharakterystyka taktychnykh pryiomiv psykholohichnoho vplyvu u kryminalistychnii diialnosti slidchoho [Characteristics of tactics of psychological influence in the criminalistic activity of the investigator]. Kryminalistychnyi visnyk. 2014. №1 (21). S.45-52. (in Ukrainian).

5. Shynkarenko I.O. Osoblyvosti komunikatyvnoi kompetentnosti slidchykh [Features of communicative competence of investigators.]. Psykholohichni zasady zabezpechennia sluzhbovoi diialnosti pratsivnykiv pravookhoronnykh orhaniv: materialy II Vseukrainskoi naukovo-praktychnoi konferentsii (v avtorskii redaktsii), (m. Kryvyi Rih, 07 liutoho 2019 roku). Kryvyi Rih, 2019. S.291-294. (in Ukrainian). 


\section{Питання психології}

\section{Резюме}

Чепур О. А. главный судебный эксперт

Полтавского научно-исследовательского,

экспертно-криминалистического иентра МВД Украины

\section{СПЕЦИФИКА МЕХАНИЗМОВ ПСИХОЛОГИЧЕСКОГО ВЛИЯНИЯ СЛЕДОВАТЕЛЯ \\ НА ПОДОЗРЕВАЕМЫХ В ПРОЦЕССЕ ПРОФЕССИОНАЛЬНОЙ ДЕЯТЕЛЬНОСТИ}

Статья посвящена освещению механизмов и факторов психологического воздействия следователей в процессе профессиональной деятельности. Подано теоретический анализ проблемь психологического воздействия в деятельности следователя, обобщенно в теоретической модели правомерного психологического воздействия. Проанализированы механизмы и закономерности психологического влияния следователя на подозреваемого в проиессе следственных действий.

Ключевые слова: психологическое воздействие; следователи; механизмы; профессиональная деятельность; следственные действия.

\section{Summary \\ Chepur O. chief forensic expert, Poltava scientific and research criminalistics center of the Ministry of Internal Affairs of Ukraine \\ SPECIFICITY OF PSYCHOLOGICAL INFLUENCE IMPLEMENTATION MECHANISMS BY INTERROGATORS ON SUSPECTS IN THE PROFESSIONAL ACTIVITY PROCESS}

Introduction. Given the main purpose of the investigator - the disclosure of the crime - the specific difficulties that the employee has to face are natural, because in almost all cases a person suspected of committing a crime tries to oppose the investigation, hide the facts, put forward false motives and sequence actions that often require the use of psychological influence.

Purpose. The purpose of this article is to describe the mechanisms and patterns of psychological influence of investigators on suspects in the course of professional activity

Methods. The main research methods were general psychodiagnostic methods (questionnaires, surveys, observations) and statistical methods (factor analysis).

Originality. the essence of psychological influence in investigative actions is quite multifaceted and requires empirical comprehension, which was noted by the author earlier (Babenko OO [1]). Based on the generalization of the results of the theoretical analysis of this problem, a model of legitimate psychological influence in investigative actions has been developed. This model describes two aspects of this influence: the aspect of the subjective characteristics of the investigator and the situational and object aspects of the psychological influence in the investigation. In particular, this model defines consistently functioning levels of legal consciousness (Zemlyanskaya OV [2]), personal characteristics of the investigator, his behavioral characteristics, methods and types of influence, techniques of influence. Also, this model reflects the influence of situational characteristics on the process of influence and features of the object of influence.

Conclusion. Effective psychological influence is achieved through the following mechanisms: manifestations of the strategy of dominance in the behavior of the investigator; manifestations of demonstrativeness of the investigator and persistence of the employee; manifestation of traits of balance and perseverance in professional activities and interaction with the suspect; carrying out professional activities on the basis of emotional balance and attention to detail, which makes it possible to find a favorable situation for the interaction with the suspect; the ability to implement one line of conduct without "compromising" with the suspect, avoiding open conflicts and realizing the influence in a hidden form for the suspect. Effective psychological influence in the investigative process is hindered by manifestations of emotionality, sensitivity, change of the investigator's behavior strategy, achievement of "compromises" with the suspect and adjustment to him in the process of investigative actions.

Key words: psychological impact; investigators; mechanisms; professional activity; investigative actions. 